
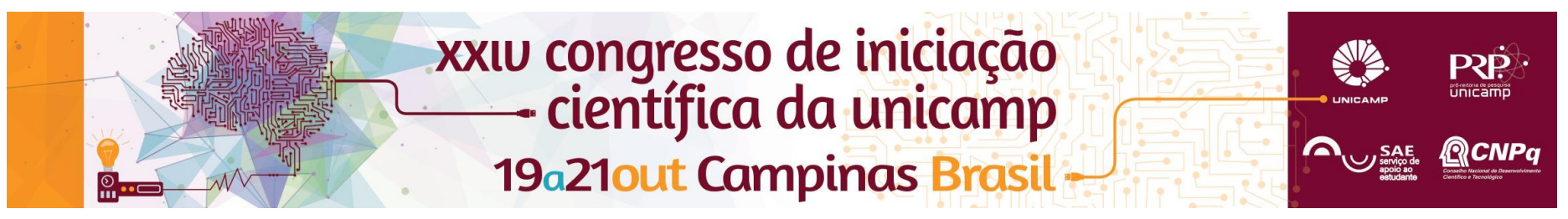

\title{
Cultivo de plantas para ensino, pesquisa e para o Jardim Botânico da Unicamp
}

\section{Franciane P. Ramos, Sara S. de Jesus, Luiza E. Mira. Orientadora Maria do Carmo E. do Amaral.}

\section{Resumo}

Este projeto tem como objetivo desenvolver pesquisas e material didático através do cultivo de plantas, que serão disponibilizadas para visitantes do Jardim Botânico da UNICAMP.

\section{Palavras-chave: \\ Biologia Floral, Casa de vegetação, Jardim Botânico.}

\section{Introdução}

Jardim Botânico será um espaço que irá proporcionar uma aproximação dos visitantes à natureza. Com nosso trabalho o jardim também conterá informações sobre as plantas, através de textos explicativos ilustrados.

\section{Resultados e Discussão}

Metodologia:

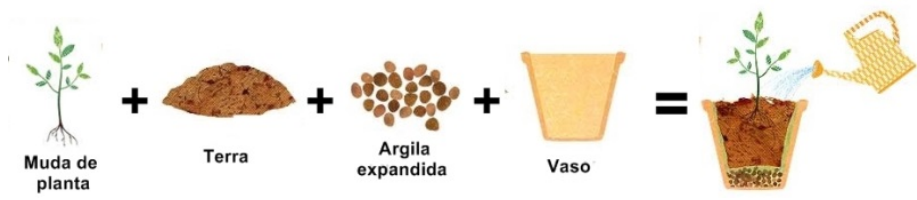

O cultivo foi feito principalmente a partir de sementes, com ênfase em plantas úteis: linhaça, gergelim, amendoim, gengibre, morango, entre outras. Muitas das que foram plantadas crescem bem com o clima e solo brasileiro, facilitando sua produção, porém algumas, por certo descuido, representado no gráfico 2 , não cresceram ou morreram, por falta de água ou excesso de sol ou as formigas se alimentaram das sementes. Algumas plantas suculentas, que são normalmente de regiões desertas, foram plantadas para testar como seria sua reação ao clima do Brasil. Após algum tempo, concluímos que, para algumas plantas suculentas, não há grande alteração em seu crescimento, chegando mesmo a florescer. Porém, se regarmos muito, suas folhas podem estourar, pois dentro delas armazena-se água. Por isso, essas plantas devem ser regadas com pouca água e com certo intervalo de tempo, para não danificar a planta. Foram elaborados textos explicativos, que serão usados nas placas do Jardim Botânico e no seu website, ficando acessíveis com auxílio de smartphones, através de códigos QR nessas placas.
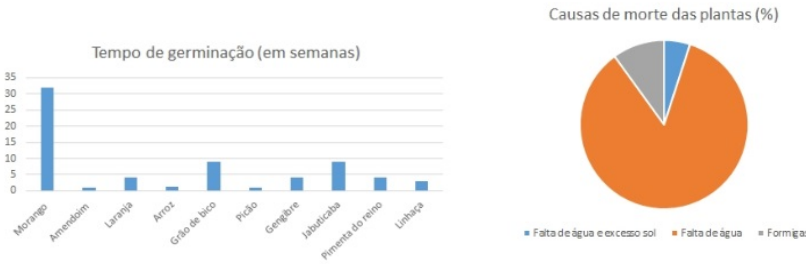
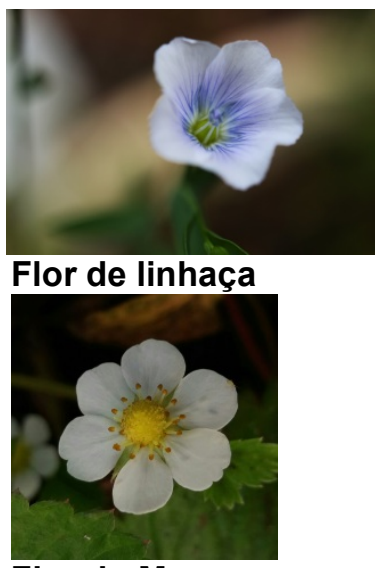

Flor do Morango

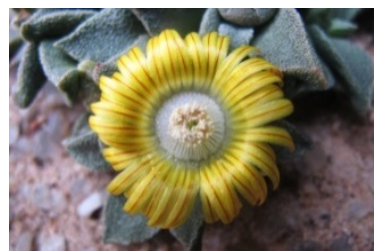

Planta suculenta do deserto

\section{Conclusões}

Durante o projeto, nós aprendemos sobre a importância das plantas na saúde, cultura e bem-estar. Com base nas pesquisas realizadas, concluímos que a falta de água e o excesso de sol influencia a mortalidade das plantas, então a quantidade que a planta recebe destes elementos deve ser observada e controlada. As plantas beneficiam os seres humanos com suas vitaminas, minerais e medicamentos, e com seu consumo, proporciona melhor qualidade de vida e o bem-estar. Os resultados obtidos serão usados futuramente no Jardim Botânico.

\section{Agradecimentos}

Agradecemos à Pró-Reitoria de Pesquisa da UNICAMP por ter nos concedido a oportunidade de fazer este projeto, à nossa orientadora, e ao CNPq por nos disponibilizar uma bolsa de estudos.

Lorenzi, Harri. Plantas daninhas do Brasil: terrestre, aquáticas, parasitas, tóxicas e medicinais. $2^{\circ}$ edição, 1991. Editora Plantarum. 